\title{
Lysosomotropic agents as HCV entry inhibitors
}

\author{
Usman A Ashfaq ${ }^{1 *}$, Tariq Javed', Sidra Rehman', Zafar Nawaz ${ }^{2}$ and Sheikh Riazuddin ${ }^{3}$
}

\begin{abstract}
HCV has two envelop proteins named as E1 and E2 which play an important role in cell entry through two main pathways: direct fusion at the plasma membrane and receptor-mediated endocytosis. Fusion of the HCV envelope proteins is triggered by low pH within the endosome. Lysosomotropic agents (LA) such as Chloroquine and Ammonium chloride $\left(\mathrm{NH}_{4} \mathrm{Cl}\right)$ are the weak bases and penetrate in lysosome as protonated form and increase the intracellular $\mathrm{pH}$. To investigate the antiviral effect of $\mathrm{LA}$ (Chloroquine and $\mathrm{NH}_{4} \mathrm{Cl}$ ) on $\mathrm{pH}$ dependent endocytosis, HCV pseudoparticles (HCVpp) of 1a and 3a genotype were produced and used to infect liver cells. The toxicological effects of Chloroquine and $\mathrm{NH}_{4} \mathrm{Cl}$ were tested in liver cells through $\mathrm{MTT}$ cell proliferation assay. For antiviral screening of Chloroquine and $\mathrm{NH}_{4} \mathrm{Cl}$, liver cells were infected with HCVpp of $3 a$ and 1a genotype in the presence or absence of different concentrations of Chloroquine and $\mathrm{NH} 4 \mathrm{Cl}$ and there luciferase activity was determined by using a luminometer. The results demonstrated that Chloroquine and $\mathrm{NH}_{4} \mathrm{Cl}$ showed more than $50 \%$ reduction of virus infectivity at $50 \mu \mathrm{M}$ and $10 \mathrm{mM}$ concentrations respectively. These results suggest that inhibition of HCV at fusion step by increasing the lysosomal pH will be better option to treat chronic HCV.
\end{abstract}

\section{Introduction}

Hepatitis C Virus (HCV) is an enveloped, positive stranded RNA virus classified in the family of Flaviviridae. HCV causes acute and chronic hepatitis infection which can eventually lead to permanent liver damage, hepatocellular carcinoma and death. It is estimated that three to four million people are infected with HCV every year [1]. HCV genome encodes a single polyprotein precursor of just over 3000 amino acids. This polyprotein precursor is co- and posttranslationally processed by cellular (signal peptidase and signal peptide peptidase) and viral (NS2-3 and NS3-4A) proteases to yield four structural (Core, E1, E2 and P7) and six non structural (NS2, NS3, NS4A, NS4B, NS5A, NS5B) proteins. HCV envelope is formed by E1 and E2 glycoprotein heterodimers which are essential for virus entry into cells [2]. HCV E1 and $\mathrm{E} 2$ fusion was enhanced at low $\mathrm{pH}$, suggesting that $\mathrm{HCV}$ enters cells via the endosomal pathway and that E1 and/or E2 undergo conformational modifications that allow fusion of viral and cellular membranes [3].

There are six major and more than 80 subtypes of $\mathrm{HCV}$. This classification is based on nucleotide variation among different $\mathrm{HCV}$ isolates. They occur in different

\footnotetext{
* Correspondence: usmancemb@gmail.com

'Division of Molecular Medicine, National Centre of Excellence in Molecular Biology, University of the Punjab, Lahore, Pakistan

Full list of author information is available at the end of the article
}

proportion in different parts of the world. Genotype 1a and $1 \mathrm{~b}$ are the most common genotypes in the United States and Europe [4,5]. The most prevalent HCV genotype in Pakistan is 3a followed by $3 \mathrm{~b}$ and 1a [6].

Presently, there is no vaccine available for prevention of $\mathrm{HCV}$ infection due to high degree of strain variation. Current therapeutic options for hepatitis $\mathrm{C}$ are limited, especially for genotype 1 . For genotypes 2 and 3, pegylated interferon in combination with ribavirin, can lead to a sustained virological response in up to $80 \%$ of patients [7]. However, this therapy is expensive and often associated with side effects that may lead to discontinuation of therapy [8]. Hemolytic anemia, cough, shortness of breath \& treatogenicity are the most common adverse effect associated with ribavirin treatment, and muscle aches, fatigue \& neuropsychiatric adverse effects of IFN$\alpha$ lead to premature cessation of therapy in 10 to $20 \%$ of patients $[9,10]$. Moreover, cost of interferon for 6 month treatment ranging from PKR 50,000 to 150,000 is beyond the financial range of most patients. Hence, there is a need to develop anti HCV agents, which are less toxic, more efficacious and cost-effective.

The term "lysosomotropic agent" was introduced by DeDuve and co-workers (1974) to designate substances that are taken up selectively into lysosomes. This definition leaves open the chemical nature of a lysosomotropic substance and the mechanism of its uptake. 
Lysosomotrpic agents such as $\mathrm{NH}_{4} \mathrm{Cl}$, chloroquine and methylamine penetrate acidic compartments of the cell and accumulate as protonated forms, resulting in an increase in the intravesicular $\mathrm{pH}$ [11-13].

Chloroquine, which is widely used for the treatment of malaria, is a well-established inhibitor of autophagic proteolysis which acts by inhibiting acidification of lysosomes and endosomes [14]. It has been reported that lysosomotropic agents such as Chloroquine and $\mathrm{NH}_{4} \mathrm{Cl}$ exert direct antiviral effects on several RNA viruses including coronaviruses, flaviviruses and human immunodeficiency virus (HIV) [15-18]. Moreover, clinical studies have demonstrated the safety, tolerability, and efficacy of lysosomotropic agents in the antiviral treatment of HIV infection $[19,20]$.

In the current study HCV entry is blocked by Lysosomotropic agents. Firstly toxicological analysis of Chloroquine and $\mathrm{NH}_{4} \mathrm{Cl}$ were done in liver cells. After toxicological analysis, antiviral effects were studied in HCVpp of 1a and 3a genotype.

\section{Materials and methods Cell lines}

Huh-7 and HEK 293 T cells were cultured in Dulbecco's Modified Eagle medium (DMEM) supplemented with $10 \%$ fetal calf serum, $100 \mathrm{IU} / \mathrm{ml}$ penicillin and $100 \mu \mathrm{g} /$ $\mathrm{ml}$ streptomycin, at $37^{\circ} \mathrm{C}$ in an atmosphere of $5 \% \mathrm{CO}_{2}$. Huh-7 was kindly provided by Dr. Zafar Nawaz (Biochemistry and Molecular Biology Department, University of Miami, USA.

\section{Plasmids}

The pcDNA-E1E2 expression vector encoding the E1 and E2 glycoproteins (171-746) of HCV genotype 3a and $1 \mathrm{a}$, was generated by inserting into a nonpackageable, CMV promoter-driven expression construct. The CMV-Gag-Pol murine leukemia virus (MLV) packaging construct, encoding the MLV gag and pol genes, and the pTG-Luciferase plasmid provided by Dr Jaean Dubison, France.

\section{Production of HCVpp and infection: Production of HCVpp and infection}

HCVpp were produced by co-transfection of 293-T cells with equal amounts of three expression vector as described previously [21]. Supernatants containing HCVpp were harvested $48 \mathrm{~h}$ later, filtered through 0.45 $\mu \mathrm{m}$ pore-sized membranes and stored at $-80^{\circ} \mathrm{C}$ before use in infection of Huh7 cells.

\section{Cell proliferation assay}

MTT (3-[4, 5-dimethylthiazol-2-yl]-2, 5-diphenyltetrazolium bromide) is a rapid and sensitive in-vitro procedure for evaluating cellular toxicity of compounds. The MTT substance is reduced by mitochondrial succinic dehydrogenases in living cells to purple formazan crystals that are not soluble in aqueous water. The absorption of dissolved formazan in the visible region correlates with the number of viable cells [21]. To investigate cellular toxicity, $2 \times 10^{4}$ Huh-7 cells were plated into 96-well plates. After $24 \mathrm{~h}$, different concentrations of Chloroquine and $\mathrm{NH}_{4} \mathrm{Cl}$ were added and the plate was sealed and kept at $37^{\circ} \mathrm{C}$ in an atmosphere of $5 \% \mathrm{CO}_{2}$ for $24 \mathrm{~h}$. After $24 \mathrm{~h}$, fresh media $(100 \mu \mathrm{l})$ and MTT solution $(5 \mathrm{mg} / \mathrm{ml}$ in PBS) were added to all wells in Columns 1-11. Wrapped the plate in aluminium foil and incubated for 3-4 $\mathrm{h}$ at $37^{\circ} \mathrm{C}$. Media was carefully removed and added $100 \mu \mathrm{l}$ of DMSO to dissolve the formazan crystals in Columns 111. MTT formazan product was determined by measuring absorbance with an enzyme-linked immunosorbent assay (ELISA) plate reader at a test wavelength of 570 $\mathrm{nm}$ and a reference wavelength of $620 \mathrm{~nm}$.

Cell viability was obtained using the following equation.

Percent cell viability $=($ Test $570 \mathrm{~nm}-650 \mathrm{~nm} /$ Control $570 \mathrm{~nm}-620 \mathrm{~nm}) \times 100$

\section{Antiviral analysis of Chloroquine and $\mathrm{NH}_{4} \mathrm{Cl}$}

To investigate anti-fusion effect of Chloroquine and $\mathrm{NH}_{4} \mathrm{Cl}$, Huh-7 cells were incubated in the presence or absence of Chloroquine and $\mathrm{NH}_{4} \mathrm{Cl}$ at $37^{\circ} \mathrm{C}$ for $30 \mathrm{~min}$. After 30 min Huh-7 cells were infected with HCVpp of $3 \mathrm{a}$ and $1 \mathrm{a}$ genotype in the presence or absence of different concentrations of Chloroquine and $\mathrm{NH}_{4} \mathrm{Cl}$ and incubated for additional $24 \mathrm{~h}$. After $24 \mathrm{~h}$ cells were lysed and luciferase activity was determined by using a luminometer.

\section{Statistical Analysis}

All statistical analysis was done using SPSS software (version 16.0, SPSS Inc). Data are presented as mean \pm SD. Numerical data were analyzed using student's t-test and ANOVA. P value $<0.05$ was considered statistically significant.

\section{Results}

\section{MTT Cell Proliferation Assay}

MTT assay is a widely used test for evaluating cytotoxicity of compounds/herbs in cell cultures. The MTT substance is reduced by mitochondrial succinic dehydrogenases in living cells to purple formazan crystals that are not soluble in aqueous water. The absorption of dissolved formazan in the visible region correlates with the number of alive cells [21]. Cytotoxic effects of Chloroquine and $\mathrm{NH}_{4} \mathrm{Cl}$ were analyzed after $24 \mathrm{~h}$ incubation of Huh-7 cells with different 
concentrations of compounds. Figure 1 showed that cell proliferation of liver cells is unaffected at high concentration. After toxicological analysis through MTT proliferation assay, antiviral activities of Chloroquine and $\mathrm{NH}_{4} \mathrm{Cl}$ were tested at non toxic concentrations.

\section{HCVpp infection is $\mathrm{pH}$ dependent}

Enveloped viruses enter cells through two main pathways: direct fusion at the plasma membrane and receptor-mediated endocytosis. Fusion of the viral envelope protein(s) is triggered by low $\mathrm{pH}$ within the endosome. Lysosomotropic agents such as Chloroquine and $\mathrm{NH}_{4} \mathrm{Cl}$, have been used to demonstrate the $\mathrm{pH}$ sensitivity of virus entry. We therefore tested the infectivity of HCVpp after treatment of target cells with different concentrations of Chloroquine and $\mathrm{NH}_{4} \mathrm{Cl}$. HCVpp of 1a and 3a genotype demonstrated dose- dependent inhibition in the presence of Chloroquine and $\mathrm{NH}_{4} \mathrm{Cl}$. Chloroquine and $\mathrm{NH}_{4} \mathrm{Cl}$ showed greater than $50 \%$ reduction of virus infectivity at $50 \mu \mathrm{M}$ and $10 \mathrm{mM}$

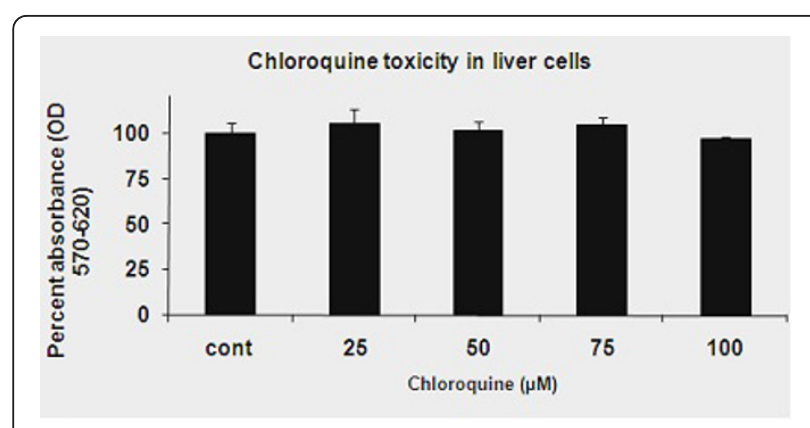

b)

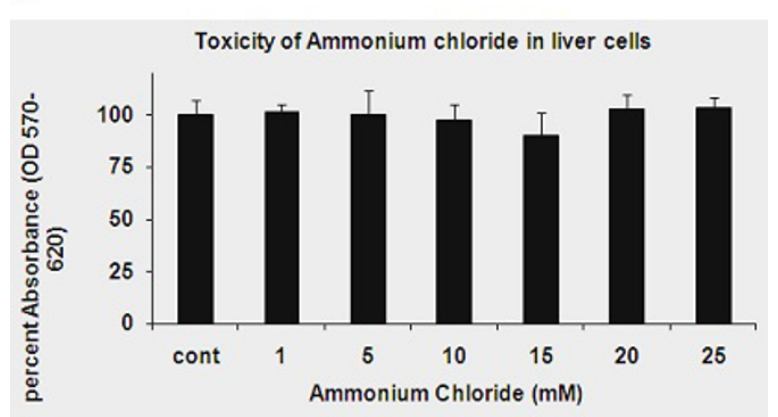

Figure 1 Toxicological study of Chloroquine and $\mathrm{NH}_{4} \mathrm{Cl}$ in Huh7 cells: Huh-7 cells were plated at the density of $2 \times 10^{4}$ in 96 well plates. After $24 \mathrm{~h}$ cells were treated with different concentrations of chloroquine and $\mathrm{NH}_{4} \mathrm{Cl}$ and control consisted of solvent in which compound dissolved. After $24 \mathrm{~h}$ incubation period add MTT solution to all wells and incubated for $3-4 \mathrm{~h}$ at $37^{\circ} \mathrm{C}$. Viable cells convert MTT to purple formazan crystal. Added DMSO to dissolve the formazan crystals and read absorbance at $570 \mathrm{~nm}$ and $620 \mathrm{~nm}$. (a) Toxicological analysis of Chloroquine in Huh-7 cells through MTT cell proliferation assay. (b) Toxicological analysis of $\mathrm{NH}_{4} \mathrm{Cl}$ in Huh-7 cells through MTT cell proliferation assay. concentration respectively, suggesting a $\mathrm{pH}$-sensitive route of virus entry (Figure 2a and $2 b$ ).

\section{Discussion}

$\mathrm{HCV}$ entry is a multistep process requiring four cellular receptor, fusion and endocytosis. HCV fusion depends on E1 and E2, viral dose, and occurs within a specific $\mathrm{pH}$ range. Targeting $\mathrm{pH}$ dependent endocytosis is a useful tool to identify antiviral drugs against. A major advancement to look into $\mathrm{HCV}$ entry process was the development of $\mathrm{HCVpp}$, consisting of native $\mathrm{HCV}$ envelope glycoproteins, E1 and E2, assembled onto

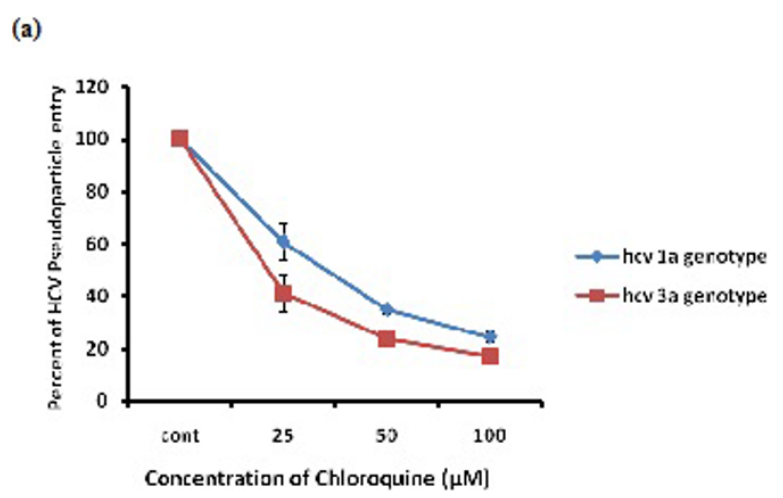

(b)

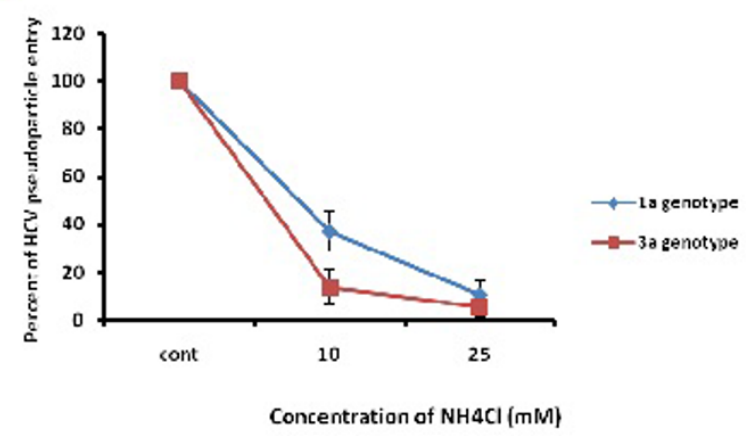

Figure 2 Dose-dependent inhibition of HCVpp of $3 a$ and 1a genotype with lysosomotropic agents. HCVpp were produced in HEK 293 T cells and collected in media after filtration in 0.45 micron filter. Huh-7 cells were incubated in the presence or absence of Lysosomotropic agents such as Chloroquine and $\mathrm{NH}_{4} \mathrm{Cl}$ at $37^{\circ} \mathrm{C}$ for 30 min. After 30 min Huh-7 cells were infected with HCVpp of 3a and 1a genotype in the presence or absence of different concentrations of lysosomotropic agents and incubated for additional $24 \mathrm{~h}$. After $24 \mathrm{~h}$ cells were lysed and luciferase activity was determined by using a luminometer. Luciferase activity is not reported as an absolute value, but is calculated relative to the 'no drug' condition and reported on the $y$-axis as a percentage. Results are represented as the average and standard error for three independent experiments. (a) Dose-dependent inhibition of Chloroquine against HCVpp of 1a and 3a genotype. (b) Dosedependent inhibition of $\mathrm{NH}_{4} \mathrm{Cl}$ against HCVpp of $1 \mathrm{a}$ and $3 \mathrm{a}$ genotype. P value $>0.05$ vs control was considered as statistically significant. 


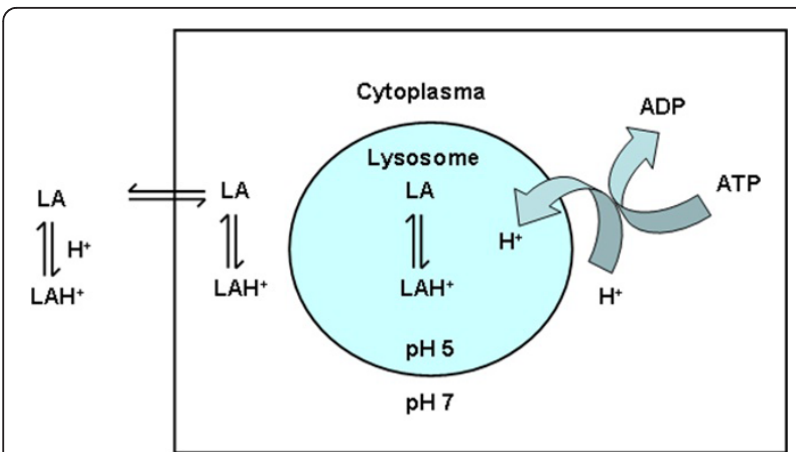

Figure 3 Schematic model of lysosomal pH maintenance and intrasomal trapping of lysosomal agents (LA) or weak bases.

retroviral core particles $[3,22,23]$. This system is potentially very powerful tool to identify and characterize molecules that block HCV entry. In this study, HCVpp of local HCV genotype $3 \mathrm{a}$ and $1 \mathrm{a}$ were produced to study early entry steps mediated by HCV envelope glycoproteins. This assay is based on the quantification of retroviral DNA synthesis, which occurs soon after the fusion of the retroviral particle with a cellular membrane. Presumably, this assay is only dependent on the entry steps mediated by the heterodimer E1E2 (binding, endocytosis, and fusion) and on the activity of the reverse transcriptase of the HCVpp retroviral core.

The intracellular sub-compartments such as lysosomes and endosomes have an acid nature with $\mathrm{pH}$ of about 5 [14]. Lysosomotropic agents such as Chloroquine and $\mathrm{NH}_{4} \mathrm{Cl}$ are weak bases which have a tendency to accumulate in these compartments. Lysosomotropic agents are captured by protonation inside the lysosomes and accumulate there (Figure 3). The ratio of intra/extra lysosomal concentrations of these substances is equal to the ratio of concentration of hydrogen ions in lysosomes and in their vicinity, i.e. $1: 100$ if we suppose that $\mathrm{pH}$ in lysosomes is 5 and in cytoplasm 7. The amount of the permeable form of lysosomotropic agents passing through the membrane depends on the substance pKa value and $\mathrm{pH}$ value of solution. The higher the $\mathrm{pKa}$ value, the lower the permeable form ratio. This has led to the assumption that the specific uptake of lysosomotropic substances into lysosomes depends on the acidic $\mathrm{pH}$ of these compartments, ion-trapping weak bases [13]. In this model, the most suitable weak bases are those with a pKa around 8 .

$\mathrm{NH}_{4} \mathrm{Cl}$ and Chloroquine are lysosomal weak bases that are known to affect acid vesicles leading to dysfunction of several proteins. Previous studies of Chloroquine and

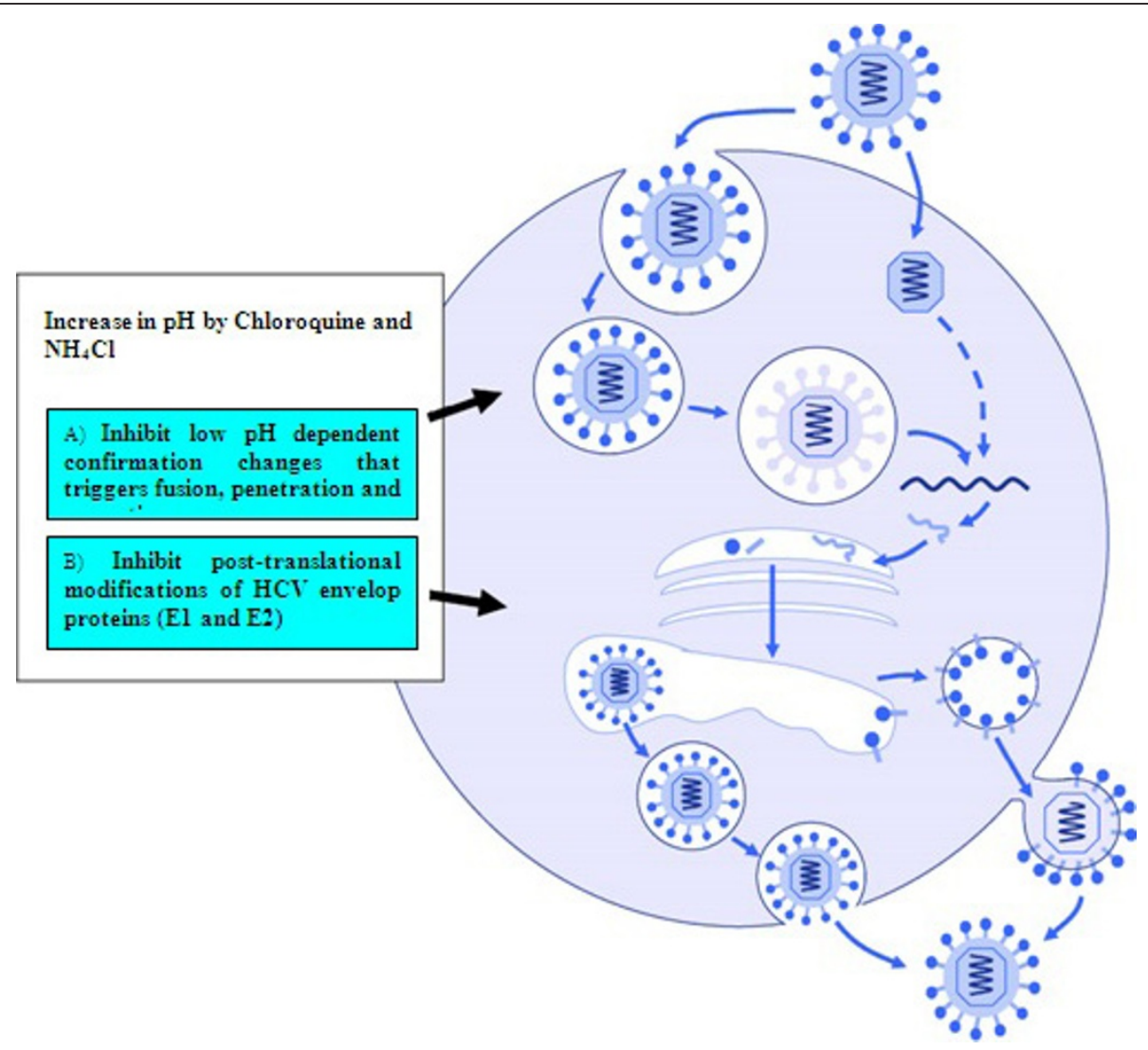

Figure 4 Schematic representation of Inhibition of $\mathrm{HCV}$ by Increase the $\mathrm{pH}$ through Chloroquine and $\mathrm{NH}_{4} \mathrm{Cl}$. 
$\mathrm{NH}_{4} \mathrm{Cl}$ have demonstrated that it has multiple effects on mammalian cells in addition to the elevation of endosomal $\mathrm{pH}$, including the prevention of terminal glycosylation of immunoglobulin's [24]. When added to virusinfected cells, chloroquine inhibited later stages in vesicular stomatitis virus maturation by inhibiting the glycoprotein expression at the cell surface [25], and it inhibited the production of infectious HIV-1 particles by interfering with terminal glycosylation of the glycoprotein $[26,27]$. Increase in $\mathrm{pH}$ by Chloroquine and $\mathrm{NH}_{4} \mathrm{Cl}$, firstly inhibits low $\mathrm{pH}$ confirmational changes that triggers fusion, penetration and uncoating and secondly inhibits posttranslational modification of HCV enveloped proteins (E1 and E2) (Figure 4). Our results demonstrated that, Chloroquine and $\mathrm{NH}_{4} \mathrm{Cl}$ inhibit HCVpp entry in a dose-dependent manner at non toxic concentration. Chloroquine and $\mathrm{NH}_{4} \mathrm{Cl}$ resulted in greater than $50 \%$ reduction of virus infectivity at a concentration of $50 \mu \mathrm{M}$ and $10 \mathrm{mM}$ respectively, suggesting a $\mathrm{pH}$-sensitive route of virus entry (Figure $2 \mathrm{a}$ and $2 \mathrm{~b}$ ).

In conclusion, inhibition of HCV entry by increasing the $\mathrm{pH}$ through lysosomotropic agents is an important target to identified new drugs against $\mathrm{HCV}$ and combination of lysosomotropic agents with interferon will be better option to treat chronic HCV.

\section{Abbreviations \\ HCV: Hepatitis C virus; LA: Lysosomotropic agents; Huh-7: Human Hepatoma Cell line.}

\section{Acknowledgements}

Financial support by Higher Education Commission Pakistan is highly acknowledged.

\section{Author details}

${ }^{1}$ Division of Molecular Medicine, National Centre of Excellence in Molecular Biology, University of the Punjab, Lahore, Pakistan. ${ }^{2}$ Braman Family Breast Cancer Institute, University of Miami, USA. ${ }^{3}$ Allama Iqbal Medical College, University of Health sciences, Lahore, Pakistan.

\section{Authors' contributions}

UAA, TJ and SDR contributed equally in lab work and manuscript write up. ZN and SRD were the principal investigator and provide all facilities to complete this work. All the authors read and approved the final manuscript.

\section{Authors' information}

Usman Ali Ashfaq (PhD Molecular Biology), Imran shahid (M Phil Molecular Biology), Tariq Javed (M. Phil pharmaceutical chemistry, Sidra Rehman (MSc Chemistry) and Sheikh Riazuddin (PhD molecular Biology and Dean Post graduate study at Allama Iqbal medical college, Lahore

\section{Competing interests}

The authors declare that they have no competing interests.

Received: 8 February 2011 Accepted: 12 April 2011

Published: 12 April 2011

\section{References}

1. Thomson BJ, Finch RG: Hepatitis C virus infection. Clin Microbiol Infect 2005, 11:86-94.

2. Flint $M$, MCKeating JA: The role of the hepatitis $C$ virus glycoproteins in infection. Rev Med Virol 2000, 10:101-117.
3. Hsu M, Zhang J, Flint M, Logvinoff C, Cheng-Mayer C, Rice CM, McKeating JA: Hepatitis C virus glycoproteins mediate $\mathrm{pH}$-dependent cell entry of pseudotyped retroviral particles. Proc Natl Acad Sci USA 2003, 100:7271-7276.

4. McOmish F, Yap PL, Dow BC: Geographical distribution of hepatitis C virus genotypes in blood donors: an international collaborative survey. J Clin Microbiol 1994, 32:884-892.

5. Nousbaum JB, Pol S, Nalpas B, Group atCS: Hepatitis C virus type 1b (II) infection in France and Italy. Ann Intern Med 1995, 122:161-168.

6. Idrees $M$, Riazuddin S: Frequency distribution of hepatitis $C$ virus genotypes in different geographical regions of Pakistan and their possible routes of transmission. BMC Infect Dis 2008, 8:69.

7. Flamm SL: Chronic hepatitis C virus infection. Jama 2003, 289:2413-2417.

8. Cornberg M, Wedemeyer H, Manns MP: Treatment of chronic hepatitis C with PEGylated interferon and ribavirin. Curr Gastroenterol Rep 2002, 4:23-30.

9. Khakoo S, Glue P, Grellier L, Wells B, Bell A, Dash C, Murray-Lyon I, Lypnyj D, Flannery B, Walters $K$, Dusheiko GM: Ribavirin and interferon alfa-2b in chronic hepatitis $C$ : assessment of possible pharmacokinetic and pharmacodynamic interactions. Br J Clin Pharmacol 1998, 46:563-570.

10. Russo MW, Fried MW: Side effects of therapy for chronic hepatitis $C$. Gastroenterology 2003, 124:1711-1719.

11. Oda K, Ikehara Y: Weakly basic amines inhibit the proteolytic conversion of proalbumin to serum albumin in cultured rat hepatocytes. Eur $J$ Biochem 1985, 152:605-609.

12. Oda K, Koriyama Y, Yamada E, Ikehara Y: Effects of weakly basic amines on proteolytic processing and terminal glycosylation of secretory proteins in cultured rat hepatocytes. Biochem J 1986, 240:739-745.

13. de Duve C, de Barsy T, Poole B, Trouet A, Tulkens P, Van Hoof F: Commentary. Lysosomotropic agents. Biochem Pharmacol 1974, 23:2495-2531.

14. Poole B, Ohkuma S: Effect of weak bases on the intralysosomal pH in mouse peritoneal macrophages. J Cell Biol 1981, 90:665-669.

15. Vincent MJ, Bergeron E, Benjannet S, Erickson BR, Rollin PE, Ksiazek TG, Seidah NG, Nichol ST: Chloroquine is a potent inhibitor of SARS coronavirus infection and spread. Virol J 2005, 2:69.

16. Savarino A, Boelaert JR, Cassone A, Majori G, Cauda R: Effects of chloroquine on viral infections: an old drug against today's diseases? Lancet Infect Dis 2003, 3:722-727.

17. Savarino A, Gennero L, Chen HC, Serrano D, Malavasi F, Boelaert JR, Sperber K: Anti-HIV effects of chloroquine: mechanisms of inhibition and spectrum of activity. Aids 2001, 15:2221-2229.

18. Di Trani L, Savarino A, Campitelli L, Norelli S, Puzelli S, D'Ostilio D, Vignolo E, Donatelli I, Cassone A: Different $\mathrm{pH}$ requirements are associated with divergent inhibitory effects of chloroquine on human and avian influenza A viruses. Virol J 2007, 4:39.

19. Sperber K, Chiang G, Chen H, Ross W, Chusid E, Gonchar M, Chow R, Liriano O: Comparison of hydroxychloroquine with zidovudine in asymptomatic patients infected with human immunodeficiency virus type 1. Clin Ther 1997, 19:913-923.

20. Paton NI, Aboulhab J: Hydroxychloroquine, hydroxyurea and didanosine as initial therapy for HIV-infected patients with low viral load: safety, efficacy and resistance profile after 144 weeks. HIV Med 2005, 6:13-20.

21. Mosmann T: Rapid colorimetric assay for cellular growth and survival: application to proliferation and cytotoxicity assays. J Immunol Methods 1983, 65:55-63.

22. Bartosch B, Dubuisson J, Cosset FL: Infectious hepatitis C virus pseudoparticles containing functional E1-E2 envelope protein complexes. J Exp Med 2003, 197:633-642.

23. Drummer HE, Maerz A, Poumbourios P: Cell surface expression of functional hepatitis C virus E1 and E2 glycoproteins. FEBS Lett 2003, 546:385-390.

24. Thorens B, Vassalli P: Chloroquine and ammonium chloride prevent terminal glycosylation of immunoglobulins in plasma cells without affecting secretion. Nature 1986, 321:618-620.

25. Dille BJ, Johnson TC: Inhibition of vesicular stomatitis virus glycoprotein expression by chloroquine. J Gen Virol 1982, 62(Pt 1):91-103.

26. Tsai WP, Nara PL, Kung HF, Oroszlan S: Inhibition of human immunodeficiency virus infectivity by chloroquine. AIDS Res Hum Retroviruses 1990, 6:481-489. 
27. Savarino A, Lucia MB, Rastrelli E, Rutella S, Golotta C, Morra E, Tamburrini E, Perno CF, Boelaert JR, Sperber K, Cauda R: Anti-HIV effects of chloroquine: inhibition of viral particle glycosylation and synergism with protease inhibitors. J Acquir Immune Defic Syndr 2004, 35:223-232.

doi:10.1186/1743-422X-8-163

Cite this article as: Ashfaq et al:: Lysosomotropic agents as HCV entry inhibitors. Virology Journal 2011 8:163.

Submit your next manuscript to BioMed Central and take full advantage of:

- Convenient online submission

- Thorough peer review

- No space constraints or color figure charges

- Immediate publication on acceptance

- Inclusion in PubMed, CAS, Scopus and Google Scholar

- Research which is freely available for redistribution

Submit your manuscript at www.biomedcentral.com/submit
() Biomed Central 